\title{
ВІЙНА ЗНАКІВ АБО СЕМІОТИКА ІНФОРМАЦІЙНО-ПСИХОЛОГІЧНОЇ ВІЙНИ (НА МАТЕРІАЛІ АНГЛОМОВНОГО МАСМЕДІЙНОГО ДИСКУРСУ)
}

\section{Тарасова В. В.}

\section{ВСТУП}

В американського письменника Чарльза Бернстіна є вірш «Воєнні історії», в якому є такі рядки «War is a battle for the hearts and minds of the heartless and mindless. War is technology's uncle» ${ }^{1}$ («Війна - це боротьба за серця та уми безсердечних і нерозумних. Війна - батько технологій»). Особливо справедливими ці твердження $є$ для нових гібридних воєн XIX століття, основою яких $є$ психологічноінформаційні операції, спрямовані на маніпулятивну трансформацію масової свідомості цільової аудиторії.

Застосування технологій гібридної війни в сучасних війнах та збройних конфліктах перетворило інформаційну сферу на ключову арену протиборства, де головною зброєю стало слово. Це за допомогою слів, сказаних або несказаних, викривлених, вигаданих, тих, на які очікували, та тих, які боялись почути, Україна за 6 років російської агресії втратила частину своєї території та тисячі людських життів. У російсько-українській війні 2014 року медійний компонент виступив як головний. Усі медійні ресурси Росії працювали і працюють, щоб переконати власне населення та Україну у справедливості цієї війни та весь світ у тому, що війни взагалі не має, а $є$ лише «внутрішній український конфлікт».

Питання протидії руйнівному інформаційному-психологічному впливу Російської Федерації в умовах розв'язаної нею гібридної війни цікавлять представників різних наук - соціології, психології, політології, військової тактики та стратегії та інших. Дослідженням інформаційно-психологічних впливів на індивідуальну та масову свідомість займались провідні вітчизняні (В. Домарєв, О. Литвиненко, В. Остроухов, В. Петрик, Г. Перепелиця, Г. Почепцов, О. Старіш) та закордонні науковці (В. Крисько, А. Кудинова, А. Манойло, І. Панарін, Ш. Сулейманова, Е. Тоффлер, Х. Шрадер та інші). В умовах

${ }^{1}$ Bernstein C. War Stories. URL: http://writing.upenn.edu/epc/authors/bernstein/ poems/war_stories.html (Last accessed: 17.03.2020). 
інформаційно-психологічної війни, коли головним «засобом ураження» $\epsilon$ слово, лінгвістика не може залишатися осторонь, і саме час говорити про новий напрям філологічних досліджень - лінгвістику інформаційно-психологічної війни.

Таким чином, актуальність роботи зумовлена загальним спрямуванням сучасної когнітивної лінгвістики на розгляд реалізації позамовних сутностей мовними засобами та нагальною потребою розкриття особливостей інновацій, що об'єктивують технології використання найновіших інформаційних технологій впливу на свідомість людей.

Гіпотеза дослідження полягає у припущенні, що в семантиці інновацій-актуалізаторів технологій інформаційно-психологічної війни наявна ідеологічна конфронтація двох світів, в основі якої лежить опозиція свій/чужий, що, своєю чергою, втілюється у таких лінгвальних феноменах, як війна форми i змісту мовних знаків. Медійний інструментарій маніпулятивних когнітивних трансформацій $\epsilon$ найбільш показовим та ефективним у цій смисловій війні.

\section{1. Інформаційно-психологічні війни та сучасні мас-медіа}

Інформаційні впливи на масову свідомість існували завжди. Психологічні та інформаційні операції в різні періоди привертали до себе увагу з боку владних і військових структур. Для перемоги над єгиптянами у битві при Пелусії 525 року до н. е. цар Персії Камбіс II наказав взяти в заручники єгипетських котів. Кішки, як і інші священні тварини, володіли особливим статусом в єгипетському суспільстві. Було заборонено вбивати або навіть заподіювати найменшу шкоду кішкам, а порушників чекало жахливе покарання аж до смерті. Містофортеця Пелусій здалося завдяки використанню персами цієї однієї 3 перших «спеціальних операцій інформаційно-психологічної війни».

Заходи, які нині належать до психологічних та інформаційних операцій, успішно застосовував у XIII сторіччі Чингізхан. Так, він наказав кожному зі своїх бійців тримати по три запалені смолоскипи в руці під час нічного бою (дезінформація з метою введення противника в оману щодо кількості солдат на протилежному боці). Під час стрільби його солдати свистіли та кричали, за допомогою катапульт на територію супротивника летіли людські голови, а сам Чингізхан розповідав під час перемовин, що сила та доблесть монгольських воїнів зумовлені поїданням серця і печінки переможених ворогів (технології залякування як один з основних способів психологічних операцій).

Воєнна пропаганда, яка $є$ основою психологічних операцій, успішно застосовувалась в усіх локальних та світових війнах. Під час Другої світової війни за наказом генерала Д. Ейзенхауера американцями було 
сформовано управління психологічної війни при Верховному головнокомандуванні союзних експедиційних сил, яке визначало психологічну війну «як розповсюдження пропагандистських матеріалів, які призначені для деморалізації ворога й придушення його волі до опору, а також підвищення морального духу союзників».

Інформаційно-психологічний вплив - це дія словом, інформацією, спрямованою на свідомість людини. Його часто називають інформаційно-пропагандистською, ідеологічною, психологічною дією ${ }^{2}$.

Основою інформаційно-психологічного впливу $є$ маніпулятивний вплив на масову свідомість ${ }^{3}$, мета якого полягає у: а) внесенні в суспільну й індивідуальну свідомість ворожих, шкідливих ідей та поглядів; б) дезорієнтації та дезінформації мас; в) послабленні певних переконань, устоїв; г) залякуванні свого народу образом ворога; г) залякуванні супротивника своєю могутністю; д) врешті-решт, забезпечення ринку збуту для своєї економіки. Деструктивний вплив може здійснюватися різними методами. Основні 3 них: 1) дезінформування; 2) пропаганда; 3) диверсифікація громадської думки; 4) психологічний тиск; 5) поширення чуток.

Як вказує А.В. Манойло, інформаиійно-психологічна війна (IПВ) це сукупність різноманітних форм, методів і засобів впливу на людей із метою зміни в бажаному напрямі їх психологічних характеристик (поглядів, думок, ціннісних орієнтацій, настроїв, мотивів, установок, стереотипів поведінки), а також групових норм, масових настроїв $\mathrm{i}$ громадської свідомості загалом ${ }^{4}$.

Основою інформаційної війни є інформаційна інтервенція з метою маніпулятивного впливу. Маніпуляція - це система духовного впливу, що суперечить об'єктивним інтересам об'єкта маніпуляції, породжує в нього ілюзію, нібито він сам діє відповідно до своїх інтересів та планів, при цьому суб'єкт маніпуляції отримує виграш - досягнення власних цілей. Маніпуляція здійснюється приховано та анонімно, за обставин, які здаються сприятливими i/або природними.

Г. Почепцов зазначає, що інформаційні війни є інформаційними технологіями, що впливають на інформаційні системи, маючи на меті введення в оману масової чи індивідуальної свідомості.

\footnotetext{
${ }^{2}$ Fuller J.F.C. The Foundations of the Science of War. Saffron Walden : Books Express Publishing, 2012. P. 72.

Сучасні технології та засоби маніпулювання свідомістю, ведення інформаційних війн і спеціальних інформаційних операцій : навч. посібник / В.М. Петрик, В.В. Остроухов, О.А. Штоквиш та ін. Київ : Росава, 2006. 208 с.

${ }^{4}$ Манойло А.В. Государственная информационная политика в особых условиях : моногр. Москва : МИФИ, 2003. С. 250.
} 
У книзі відомого фахівця в галузі комунікаційних технологій Г. Почепцова «Сучасні інформаційні війни» введене поняття смислової війни. На думку автора, нинішній конфлікт між Україною та Росією представляє собою першу смислову війну у світі, а перемога на полі бою не є достатньою перемогою, бо, насамперед, потрібна перемога в головах. Смислова війна є довготривалою і зайнята не так фактами, скільки зміною інтерпретацій фактів, щоб опонент прийняв потрібне для атакуючої сторони рішення ${ }^{5}$. Також для позначення такого різновиду технологій використовують терміни «консиієнтальна війна» та «семантична війна». Консцієнтальна війна (лат. conscientia свідомість, сумління) - війна на ураження свідомості, руйнування ідентичності, а також самої здатності людини до самоідентифікації́ За визначенням С. Дацюка, семантична війна - це концептуальна війна за сенси i перспективи майбутнього: конструктивні, мережеві, загальнолюдські. Саме семантична війна створює нові дискурси. Це іiі основна мета. Таким чином, семантична війна - це війна дискурсів на рівні розумових установок'

На нашу думку, обидва терміни змістовно $€$ гіпонімами до гіпероніму «інформаційно-психологічна війна». Першим цей термін вжив британський аналітик і історик Фулер (J.F.C. Fuller), який спрогнозував, що, можливо, колись виключно психологічна війна замінить традиційну війну 8 .

Дослідження комунікативних особливостей ведення інформаційнопсихологічної війни неможливе без використання категорії «стратегічний наратив». Стратегічний наратив формується на підставі наявних у суспільстві уявлень i цінностей. Стратегічний наратив - осьовий контентний елемент всієї інформаційної (в т.ч. пропагандистської) діяльності держави, на його утвердження в цільових аудиторіях спрямовується діяльність всіх комунікативних можливостей держави".

Неможливо переоцінити значення мас-медіа як агентів впливу на масову свідомість та засіб трансформації картини світу у потрібному вимірі. Ще міністр пропаганди Третього рейху Й. Геббельс казав: «Дайте мені засоби масової інформації, і я з будь-якого народу зроблю C. 450 .

${ }^{5}$ Почепцов Г.Г. Сучасні інформаційні війни. Київ : Києво-Могилян. акад., 2015.

${ }^{6}$ Колодій А. Про консцієнтальну війну і тверезий глузд у ставленні до влади. URL: https://political-studies.com/?p=1311 (дата звернення: 11.04.2020).

7 Дацюк С.A. Семантична війна. URL: http://virtualpsylab.chnu.edu.ua/?p=370 (дата звернення: 11.03.2020).

${ }^{8}$ Fuller J.F.C. The Foundations of the Science of War. Saffron Walden : Books Express Publishing, 2012. 340 p.

${ }^{9}$ Дубов Д.В. «Стратегічний наратив»: до проблеми реалізації сутності складової стратегічних комунікацій в Україні. URL: http://www.niss.gov.ua/articles/2377/ (дата звернення: 10.03.2020). 
стадо свиней». А Наполеон Бонапарт вважав: «Чотири газети зможуть принести ворогові більше зла, ніж стотисячна армія».

Г.Г. Почепцов називає журналістику XIX століття «nостжурналістикою», а іiї головною рисою - використання вільних чи квазівільних ЗМІ для позаінформаційних цілей ${ }^{10}$.

У книзі «Новини пласкої Землі» відомий британський журналістрозслідувач Н. Дейвіс називає сучасну журналістику чурналістикою (дурналістикою) («churnalism») ${ }^{11}$. Це квазіжурналістика, заснована на переписуванні піар-матеріалів та позбавлена етичних й правових норм, цинічне завдання якої полягає у формуванні громадської думки (в сенсі маніпуляції масовою свідомістю), а також управлінні почуттями i вчинками людей. Сучасні засоби масової інформації $\epsilon$ одним iз головних засобів інформаційно-психологічної війни.

Внаслідок зростаючої ролі мас-медіа як каналів маніпулятивного впливу на суспільство виникла нова спеціалізація - spindoctor, завданням якого стає зміна сприйняття події. Spindoctor - a person who provides a favourable slant to an item of news, potentially unpopular policy, etc, esp on behalf of a political personality or party (укр. - спіндоктор, піарник, політтехнолог, експерт зі зв'язків із громадськістю, пресою (забезпечує подачу інформації в ЗМІ під потрібним кутом зору) ${ }^{12}$.

Для популяризації своїх позицій Росія створила, фінансує і розвиває кілька дуже потужних міжнародних інформаційних мереж. Наприклад, телевізійна компанія Russia Today (RT) здійснює мовлення більш ніж у 100 країнах світу цілою низкою мов. Крім найпотужнішої радіокомпанії Sputnik, Росією було створено однойменне псевдоновинне агентство. Маніпулятивний вплив на цільову аудиторію відбувається цілим арсеналом опосередкованих способів. Так, у Великій Британії Росія сприяла просуванню болючої теми Brexit, розуміючи, що ця ідея призведе до внутрішнього загострення протистояння в країні. У Польщі й Угорщині російські пропагандисти використовували маніпуляції, піднімаючи градус неприйняття тези «політики відкритих дверей» щодо біженців місцевим населенням. У Франції росіяни активно просували і підігрівали антиамериканські настрої для того, щоб погіршити відносини між Францією і США ${ }^{13}$.

\footnotetext{
${ }^{10}$ Почепцов Г.Г. Сучасні інформаційні війни. Київ : Києво-Могилян. акад., 2015. 496 c.

${ }^{11}$ Дейвіс Н. Новини пласкої землі. Київ : Темпора. 2011. 548 с.

12 Spindoctor. URL: https://www.collinsdictionary.com/dictionary/english/spin-doctor (Last accessed: 26.04.2020).

13 Скандал забезпечений. Як Кремль веде інформаційну війну URL: https://nv.ua/ukr/opinion/russia-today-sputnik-yak-rosiya-vikoristovuye-media50050708.html (дата звернення: 17.04.2020).
} 
У 2019 році російським інформаційним агентствам Russia Today i Sputnik заборонили відвідувати конференцію з питань свободи ЗМI в Лондоні. Таке рішення було прийнято через те, що останні відіграють «активну роль у поширенні дезінформації» ${ }^{14}$. Відмова в акредитації була офіційно видана Міністерством закордонних справ Великобританії. Президент Франції також звинуватив ці російські ЗМІ в поширенні брехні і пропаганди. Е. Макрон не дозволив російським 3MI Russia Today i Sputnik працювати у своєму передвиборчому штабі, аргументуючи рішення так: «Russia Today i Sputnik діють не як професійні журналісти, а як агенти впливу». Соцмережа Twitter заборонила розміщувати рекламу на своїй платформі російським пропагандистським каналам Russia Today i Sputnik. У компанії прийняли відповідне рішення на основі висновків американського розвідувального агентства. Вони свідчать, що Russia Today i Sputnik намагалися впливати на вибори президента США у 2016 році.

У дослідженні («Weaponising News RT, Sputnik and targeted disinformation» ${ }^{15}$ ), проведеному у 2017-2018 роках на матеріалах новин Sputnik та Russia Today (RT), британські дослідники Г. Рамсей та C. Робертшоу (Dr Gordon Ramsay, Dr Sam Robertshaw) продемонстрували механізми поширення дезінформації кремлівськими 3MI, проаналізували основні стратегічні наративи вищезгаданих засобів російської пропаганди та назвали їх основними каналами маніпулятивного впливу на англомовну аудиторію.

\section{2. Вербальна об'сктивація інформаційно-психологічної війни в сучасному англомовному масмедійному дискурсі}

Проведений аналіз контенту проросійських засобів масової інформації, спрямованих на англомовну аудиторію, показав, що основними методами маніпулювання свідомістю через канали масмедіа є спрощення (засіб перетворення складних проблем соціальнополітичної дійсності у прості), замовчування (спосіб приховування небажаної інформації для певного джерела пропаганди) і витіснення (інструмент відволікання уваги реципієнтів від негативних поточних подій), а також методи, які найбільш активно та широко використовуються в політичній сфері. До них належать: вигаданий

${ }^{14}$ Russia Today и Спутнику запретили участвовать в конференции о свободе прессы в Лондоне. URL: https://www.dsnews.ua/world/russia-today-i-sputniku-zapretiliuchastvovat-v-konferentsii-09072019141000 (Last accessed: 20.04.2020).

${ }_{15}$ Ramsay G., Robertshaw S. Weaponising news RT, Sputnik and targeted disinformation. King's College London Centre for the Study of Media, Communication \& Power. 140 p. URL: https://www.kcl.ac.uk/policy-institute/assets/weaponising-news.pdf (Last accessed: 20.04.2020). 
факт (повідомлення факту, достовірність якого не можна перевірити), пряме коментування (використання оціночних понять під виглядом нейтральних задля демонстрації позиції певної групи та забезпечення їй підтримки), непряме коментування (приховування комунікатором пропагандистського впливу через інформаційний фон або шум), двостороння аргументація (виклад кількох точок зору, альтернативні позиції не виключаються й не оцінюються як хибні), напівправда й інсинуація (надання хибної аргументації фактам, маніпулювання ними всередині матеріалу, а в деяких випадках неадекватність фактів та аргументів висновкам), інформаційне дроблення (повідомлення лише фрагменту даних, що призводить до нерозуміння ситуації і події загалом), інформаційне перевантаження (повідомлення надзвичайно великого обсягу інформації, основну частину якого складають абстрактні судження), інформаційно-пропагандистська індукція (розташування та підбір повідомлень, що будується за принципом «від часткової правди до загальної неправди»), семантичне маніпулювання.

I.M. Панарін пише, що сутність «методу семантичного маніпулювання» полягає в ретельному доборі слів або 3 позитивною або 3 негативною конотацією, впливаючи цим на сприйняття інформації (наша людина - розвідник, їхня людина - шпигун) $)^{16}$.

Культурно маркована дихотомія СВІЙ/ЧУЖИЙ виступає однією 3 фундаментальних бінарних опозицій і лежить в основі формування культурної, ідеологічної ідентичності. Проекцією опозиції СВІЙ/ЧУЖИЙ в інформаційно-психологічній війні виступає протиставлення Росія/Україна, тобто мова віддзеркалює стосунки між відповідними сторонами, при цьому відбувається концептуалізація учасників конфлікту в термінах базових цінностей ДОБРА і ЗЛА: «Путлерівська» Росія та ОРДЛО - ЗЛО; Україна - ДОБРО, та навпаки, «Русский мир» та (рос.) «ополченцы» - ДОБРО; (рос.) «бендеровцы» та (рос.) «киевская хунта»-ЗЛО.

Як зазначає А.Б. Семенчук, позиція СВІЙ/ЧУЖИЙ відбивається в лінгвальному феномені війни мовних знаків, який включає війну форми мовних знаків та війну змісту мовних знаків. Так, війна форми мовних знаків передбачає використання протилежними сторонами різних мовних засобів для позначення одних і тих самих суб'єктів, подій, явищ ${ }^{17}$. Ілюстрацією зазначеного явища $\epsilon$ (рос.) «ополченцыљ» (англ. insurgents (повстаниі) і (укр.) «терористи». Тобто одну й ту саму

${ }^{16}$ Панарин И.Н. Технология информационной войны : моногр. Москва : КСП, 2003. $320 \mathrm{c}$.

17 Семенчук А.Б. Інноваційні засоби об'єктивації концепту тероризм (на матеріалі англійської мови) : автореф. дис. ... канд. філол. наук : 10.02.04. Херсон, 2010. C. 5. 
особу можна одночасно розглядати і як терориста, і як борця за свободу залежно від того, на боці якої зі сторін конфлікту вона знаходиться.

Наприклад: But when it comes to the legitimate resistance in Donbass and in the temporarily occupied parts of Novorossiya, when it comes to the peoples militia and the Army of Novorossiya, then the west suddenly calls them separatists and terrorists, when in reality they are freedom-fighters. $!^{18}$

Як зазначає Г. Почепцов, знакове уявлення ситуації зумовлює нашу реакцію на неї, оскільки символічні складники виявляються основними для вироблення тих чи інших дій ${ }^{19}$. Вибір слова (знакове оформлення) вказує на тип відношення до цього об'єкта, а не тільки відсилає на нього. 3 точки зору семіотики телевізійні новини не тільки задають інтерпретацію подій, але і вказують на офіційний характер цієї інтерпретації, оскільки диктори завжди постають перед нами в офіційному одязі, говорять літературною мовою і т.д.

Під час війни світ принципово стає тільки чорно-білим. Ворог поганий вже спочатку, з моменту свого народження. Різноманітні метафори для позначення ворога - необхідний компонент будь-якого збройного конфлікту. Вони служать своєрідними культурними знаками, що відображають поляризацію між групами СВІЙ/ЧУЖИЙ.

Українську владу, сформовану після втечі В. Януковича, в багатьох російських ЗМІ називали «хунтою», прихильників Свромайдану іменували «фашистами» («неофашистами»), в соціальних мережах поширилася інвективна лексика: українців почали називати рос. «майданутыми», «майдаунами», «украми», «укропами», «салоедами», «свидомитами», «бендеровиами», «вышиватниками». Проросійська пропаганда почала транслювати ці поняття і на англомовну аудиторію. Наприклад: banderovtsy, banderlogi (Russian synonyms for neo-Nazis, literally followers of World War II-era Ukrainian nationalist Stepan Bandera), ukry, ukropy, maidanuty (a rather unfeeling term targeting proUkraine sympathizers who took part in Maidan protests), pravoseki (a member of Pravy Sektor, or Right Sector, an ultranationalist Ukrainian group that took part in the Maidan protests).

За роки російсько-українського протистояння з'явилося чимало номінацій-неологізмів на позначення громадян РФ та так званих «ЛНР» і «ДНР». Наприклад: separ (a shorten version of the word "separatist" and it is now commonly used to define the residents of Donbas, who want separation from Ukraine and often support joining Russia), putinoid (a self-

${ }^{18}$ There are real Nazis in power in Kiev. URL: https://www.geopolitica.ru/en/article/ there-are-real-nazis-power-kiev (Last accessed: 22.04.2020).

${ }^{19}$ Почепцов Г.Г. Сучасні інформаційні війни. Київ : Києво-Могилян. акад., 2015. C. 196 . 
explanatory epithet is reserved for fans of Russian President Vladimir Putin), valenki (ignorant Russian fools), kolorady (Ukrainians came up with this unfriendly nickname - short for Colorado potato beetles - to mock people wearing the St. George ribbon, a symbol adopted by pro-Russian separatists in eastern Ukraine) $)^{20}$.

Ці неологізми містять негативну конотацію, вказуючи на певні характеристики учасників збройного протистояння.

За роки російсько-українського протистояння поширеними стали неологізми ватники, вата (росіяни та українці, які підтримують ідею «руського міра» та прагнуть повернути радянське минуле). Наприклад:

The vatnik is representative of a certain archetypical Russian who slavishly supports the regime out of fear, hatred of others, or most often a combination of both. All vatnik images have two key facial features. His nose is red from non-stop consumption of Putinka brand vodka, and one eye has been blackened from a fistfight with some other vatnik, possibly over a bottle of Putinka. The vatnik has nothing but white-hot hatred for Ukraine. He says that Ukrainians and Russians are "brother peoples" and yet despises the "invented" Ukrainian language and any cultural distinction between the two ${ }^{21}$.

Цей мем породив новий неологізм - вишиватник / vyshyvatnik (a mixture of vatnik and vyshyvanka - Ukraine's traditional embroidered shirt) is an antipode of vatnik and defines a person who implicitly trusts Ukrainian propaganda and blindly hates everything related to Russia).

Анексія Росією українського Криму збагатила словники ще кількома популярними неологізмами - зелені чоловічки / the little green men (the little green men refers to the Russian soldiers who didn't wear insignia when invading the peninsula. Meanwhile, Russian propaganda prepared its own term for the little green man - polite people). Наступний популярний із 2014 року інтернет-мем - кримнаш / Krymnash (Krymnash means "Crimea is ours» in Russian and reflects the excitement of the pro-Kremlin Russian residents about annexation of Crimea. It is often used in an ironic sense to highlight the vanity of this attainment for common Russians).

Популярним меседжем російської пропаганди $є$ теза, що в Україні у 2014 році захопили владу ультраправі екстремісти та радикали, які і нині фізично знищують російськомовне населення.

${ }^{20}$ Ukraine's Cryptic, Clever (And Always Insulting) Lexicon Of War. URL: https://www.rferl.org/a/ukraine-lexicon-of-war/26590324.html (Last accessed: 27.04.2020).

${ }_{21}^{2}$ Vatnost - Why the West can't Understand Russia. URL: http://readrussia.com/ 2015/06/09/vatnost-\%E2\%80\%93-why-the-west-cant-understand-russia/ (Last accessed: 29.04.2020). 
Наприклад: But an undeniable part of the draw was that Ukrainian ultranationalists, many with barely disguised neo-Nazi or white supremacist views, had been a driving force in the revolution. Researchers warn that Ukraine is radicalizing far-right foreign fighters in the same way Syria has with jihadis - albeit on a smaller scale - creating a global network of combat-tested extremists who pose a security threat that is now beginning to manifest itself ${ }^{22}$.

Дезінформація $є$ основним засобом російської пропаганди під час конфліктів, при цьому використовують терміни «фашисти» або «злочинці» для дискредитації в очах Заходу.

Ярлики «фашист», «начист», «фатизм», «пропагандист фашистської ідеологї̈, «фашистський режим» є одними 3 найбільш вживаних протягом російсько-українського протистояння, причому обома сторонами. Найзагальнішим науковим визначенням фашизму $є$ таке: «це найбільш реакційна диктатура представників фінансовомілітаристського клану». Ярлик «фашист» різні політики та ЗМІ намагаються приклеїти окремим особам, політичним діячам, партіям, організаціям, у результаті чого самі ці слова втрачають конкретне значення, проте у свідомості людей ця лексема має стійку негативну конотацію та асоціюється зі злочинами проти людства та режимами Муссоліні та Гітлера.

Наприклад: Donbass has, all alone, done all they can and much more against a fascist army that is supported by thousands of foreign mercenaries. And now any political party in fascist Ukraine that is for federalization or even equal rights for the Russians and Russian-speakers is considered 'illegal' by the Nazi junta in Kiev ${ }^{23}$.

Для пропаганди дуже важливо заволодіти традиційними словами 3 очевидною негативною оцінкою, але при цьому 3 претензією на об'єктивність. Так, з 2014 року російські ЗМІ активно почали вживати слова «хунта» і «фашисти» на позначення українців. Хунта (ісп. juntaзібрання) - військовий уряд у деяких країнах Латинської Америки, який прийшов до влади в результаті державного перевороту. Так, називаючи український уряд, призначений після Революції Гідності, хунтою, у свідомості цільової аудиторії навмисно закріплювали сему «державний переворот». Це один зі стратегічних наративів кремлівської пропаганди про те, що владу в Україні, мовляв,

${ }^{22}$ Far-Right Extremists Have Been Using Ukraine's War as a Training Ground. They're Returning Home. URL: https://www.vice.com/en_us/article/vb95ma/far-rightextremists-have-been-using-ukraines-civil-war-as-a-training-ground-theyre-returninghome (Last accessed: 27.04.2020).

${ }^{23}$ The Nazi Junta in Kiev must be brought to justice. URL: https://katehon.com/ article/nazi-junta-kiev-must-be-brought-justice (Last accessed: 27.04.2020). 
захопила «радикальна і фашистська меншість», від якої населення треба захистити. Таким чином реалізується прийом «демонізації» ворога».

Наприклад: Newspapers, TV and radio stations, even internet-sites and bloggers have been burnt, occupied or closed because they showed the truth about the nazis and the illegal regime - the Kiev nazi junta - but the west does not want to see what happens in former Ukraine ${ }^{24}$.

Також у сучасному світі дуже важливими стали слова «тероризм» $\mathrm{i}$ «терорист». Якщо вдається приліпити іншою стороною ці ярлики, то іiі дискредитація забезпечена. Наприклад: The defence ministry blamed the latest attack on 'terrorists' - the term commonly used by Ukrainian officials for armed pro-Russian separatists in Donetsk and the neighbouring Luhansk region $^{25}$.

Англомовні пропагандистські мас-медіа намагаються створити наратив, вигідний для Росії, i легітимізують іiі геополітичні устремління. Так, російське вторгнення до України та розпочата Росією війна репрезентується світові як «civil war / громадянська війна» в Україні та номінується евфемізмом «Ukrainian crisis / українська криза».

Наприклад: We've come to expect the Russian media using the language of "crisis" rather than the language of "war" precisely because it diminishes Russia's responsibility. State-run Sputnik and RT (Russia Today) have run thousands of articles about the "Ukrainian Crisis" all of which perpetuate Russian myths about Ukraine ${ }^{26}$.

Реалізація пропагандистських стратегічних наративів відбувається за допомогою конструювання певної віртуальної реальності, тобто образів, яких не існує - симулякрів. Інформаційний і віртуальний простори насичуються недостовірною інформацією, за допомогою якої відбувається вплив на індивідуальну та масову свідомість, та формується потрібне атакуючій стороні світобачення цільової групи. Прикладами симулякрів $є$ : фашисти на Майдані, звірства каральних батальйонів Яроша, історія породілля в Донецькому пологовому будинку, якій танковим снарядом перебило руки, коли вона вперше взяла в руки свою новонароджену дитину, жінка пенсійного віку 3

${ }^{24}$ There are real Nazis in power in Kiev. URL: https://www.geopolitica.ru/en/article/ there-are-real-nazis-power-kiev (Last accessed: 22.04.2020).

${ }_{25}$ War on terms: who's fighting against Ukraine in Donbas - terrorists, rebels, insurgents? URL: http://euromaidanpress.com/2019/06/04/war-on-terms-whos-fightingagainst-ukraine-in-donbas-terrorists-rebels-insurgents/ (Last accessed: 30.04.2020).

${ }^{26}$ How Russia's worst propaganda myths about Ukraine seep into media language. URL: https://www.stopfake.org/en/how-russia-s-worst-propaganda-myths-about-ukraineseep-into-media-language/ (Last accessed: 29.04.2020). 
епілепсією, яку начебто згвалтували на очах пасажирів рейсового автобусу тощо. Так, історія трирічного хлопчика, розіп'ятого на очах у матері у м. Слов'янську, вигадана російською пропагандою, породила безліч інтернет-мемів. «Розіп'ятий хлопчик» - вираз, що означає абсурдність російської пропаганди, з'явився після сюжету російського «Першого каналу» про розп'ятого трьохрічного хлопчика в Слов'янську.

Наприклад: Ukrainian officials had nailed a 3-year-old, clad in just his underwear, to a wooden board "just like Jesus," right before his mother's eyes, according to Russian state television. Then, said Galina Pyshniak, Channel One's sole witness and a pro-Russian refugee, the military in Slovyansk had grabbed the mother, tied her to a tank, and dragged her three times around the city's central Lenin Square ${ }^{27}$.

Ще одним неологізмом та популярним інтернет-мемом, «творінням» російської пропаганди став вислів «Візитка Яроша» (When the war first began, there was a popular meme circulating on the internet known as the "Yarosh Card" named after Dmitry Yarosh, then leader of the nationalist Pravy Sektr (Right Sector) movement. Ukrainian nationalists were blamed for everything under the sun, hence people began playfully photoshopping a "Yarosh" ID card at various scenes, to mock Russia's oft repeated statements that nationalists were invariably responsible for whatever ill was in the new ${ }^{28}$ ).

Російською пропагандою активно використовуються стратегічні наративи «допомоги братському народу» та «руської (слов'янської) $\epsilon \partial н о с т і »$, які тісно пов'язані з мовною ідентифікацією населення сходу України.

Наприклад: Soon after facing new sanctions from Kiev, Chechen leader Ramzan Kadyrov stated that this would not alter his brotherly attitude to the Ukrainian people, who can always expect help from Chechens and Russians in times of trouble $e^{29}$.

До інформаційного інструментарію розробників спеціальних інформаційно-психологічних інформацій входять навіть прийменники та артиклі. Суперечка про те, як треба говорити російською мовою -

${ }^{27}$ There's No Evidence the Ukrainian Army Crucified a Child in Slovyansk. URL: https://www.thedailybeast.com/theres-no-evidence-the-ukrainian-army-crucified-a-childin-slovyansk (Last accessed: 28.04.2020).

28 How Russia's worst propaganda myths about Ukraine seep into media language. URL: https://www.stopfake.org/en/how-russia-s-worst-propaganda-myths-about-ukraineseep-into-media-language/ (Last accessed: 29.04.2020).

29 Only Russia can save Ukraine, Kadyrov tells Poroshenko. URL: https://www.rt.com/russia/427734-kadyrov-russia-save-ukraine/ (Last accessed: 30.04.2020). 
«на Україні» чи «в Україні», часом схожа на справжню війну. Конфлікт прийменників стає приводом для конфліктів. В Україні наполягають: не «на», а «в». Аргумент: «в»- означає «в державі», а «на»- на певній території, яка не має державних кордонів («на Житомирщині», «на Київщині», «на Волині» та ін.) ${ }^{30}$. Проте всі російські ЗМІ та представники російського істеблішменту свідомо та навмисно, демонструючи своє імперське мислення, використовують прийменник «на». I цей вибір $є$ не філологічним, а політичним, тому що говорити, використовуючи прийменник «на», - це формально припускати, що це просто територія, Україна як окраїна, можна приїхати «на околицю», можна приїхати «на територію». А вживати прийменник «в»- це поважати суверенність держави.

З 1991 року всі інформаційні агентства Америки та Англії, всі англомовні закордонні ЗМІ перестали використовувати означений артикль поряд із назвою країни Ukraine, бо виникла незалежна держава, проте російські 3МІ, готуючи матеріали про Україну англійською мовою, навмисно використовують артикль поряд із назвою країни «the Ukraine», знаючи, що цей означений артикль маркує не країни, а підконтрольну територію.

Наприклад: Trump retorted, "Why are we the only ones that give the big money to the Ukraine?" This was wrong linguistically or, rather, geopolitico-lexicographically. Saying 'the Ukraine' is more than a grammatical mistake - it is inappropriate and disrespectful for Ukraine and Ukrainians. Attaching "the" in front of the name not only suggests that Ukraine is a "sub-part or region of a country," but it implies that Ukraine is a vassal state, a colonial territory, whereas Ukraine is no longer a part of another country or empire ${ }^{31}$.

Дедалі частіше російські ЗМІ використовують термін «Malorossiya / Малоросія», говорячи про незалежну державу Україну, та намагаючись довести улюблений кремлівський наратив, що Україна - це «недодержава».

Наприклад: Putin's spokesman stated that he would not comment on the proposed proclamation of Malorossiya, adding however that "this is subject to reflection and analysis ${ }^{, 32}$.

Своїми виступами В. Путін дав чіткий сигнал історикам та пропагандистам, що для нього Київська Русь і Росія - це поняття

30 Толстой I. Україна i Росія: мовно-політичний фронт. URL: https://www.radiosvoboda.org/a/28351574.html (дата звернення: 21.04.2020).

31 The Geopolitics of Ukraine's 'The'. URL: https://foreignpolicy.com/2019/ 10/05/ukraine-name-insult-war-russia-geography/ (Last accessed: 27.04.2020).

${ }^{32}$ Malorossiya is a Russian Idea. URL: https://warsawinstitute.org/malorossiya-is-arussian-idea/ (Last accessed: 29.04.2020). 
тотожні. Ще з весни 20014 року з російської версії Вікіпедії зник термін «Київська Русь» (Киевская Русь), а його замінили на "Давньоруська держава» (Древнерусское государство, Древняя Русь). Тобто завдяки вмілим маніпуляціям словами не тільки відбувається вплив на майбутнє, а й змінюється минуле. Щоб протистояти цим інформаційним та психологічним інтервенціям, необхідно досліджувати, як ці механізми працюють на рівні індивідуальної та масової свідомості.

\section{ВИСНОВКИ}

Сучасні війні відбуваються у віртуальному просторі. Їм не цікаве фізичне знищення супротивника, вони спрямовані на трансформацію його картини світу, таким чином, щоб він став частиною їх системи. У XXI столітті головним об'єктом атаки є не тіло, а розум.

Якщо раніше в основі інформаційної війни стояло повідомлення, то нині головною $є$ інтерпретація. Саме інтерпретаціями, а не фактами заповнений контент пропагандистських ЗМІ.

Російсько-українська смислова війна проявилася в постійній реінтерпретації ситуацій та фактів, коли з двох альтернативних джерел для опису обиралося те, яке найповніше відповідало запланованій меті.

Маніпулювання свідомістю цільової аудиторії та тиражування «правильних» меседжів ЗМІ відбувається за допомогою добору «правильних» слів, що демонізують ворога та «оспівують» велич та чесноти протилежної сторони конфлікту.

Аналіз способів та засобів об'єктивації інформаційно-психологічної війни ілюструє процес сприйняття об'єктивної дійсності крізь призму певної ідеології та менталітету. При цьому відбувається концептуалізація учасників конфлікту в термінах базових цінностей ДОБРА і ЗЛА, підгрунтям якої слугує дихотомія СВІЙ/ЧУЖИЙ. Інформаційно-психологічна війна супроводжується лінгвальним феноменом війни мовних знаків, як їх форми (використання протилежними конфліктуючими сторонами різних мовних одиниць для позначення супротивника i його діяльності), так i ïx змісту (використання протилежними конфліктуючими сторонами одних і тих самих мовних одиниць вже зі зміненою конотацією для позначення супротивника і його діяльності).

Перспективи подальших досліджень вбачаємо в аналізі контенту, комунікативних технологій, маніпулятивного інструментарію (зокрема, фейків та дезінформаціі) нових соціальних медіа як основних засобів ведення інформаційних воєн та агентів впливу на свідомість цільової аудиторії. 


\section{АНОТАЦІЯ}

Досліджено проблему об'єктивації інформаційно-психологічної війни інноваційними вербальними засобами. Здійснено семантичний аналіз інновацій, який актуалізується у феномені війни мовних знаків, що включає війну форми та змісту мовних знаків. Аналіз способів та засобів об'єктивації інформаційно-психологічної війни віддзеркалює сприйняття об'єктивної дійсності крізь призму певної ідеології та менталітету, підгрунтям якої слугує дихотомія СВІЙ/ЧУЖИЙ. Висвітлено великий арсенал методів пропаганди та основні стратегічні наративи заангажованих мас-медіа у процесі російсько-українського конфлікту. 3'ясовано особливості функціонально-прагматичної реалізації концептуальної опозиції СВІЙ/ЧУЖИЙ на матеріалі контенту англомовних мас-медіа, присвяченого Україні та Росії.

\section{ЛІТЕРАТУРА}

1. Дацюк C.A. Семантична війна. URL: http:// virtualpsylab.chnu.edu.ua/?p=370 (дата звернення: 11.03.2020).

2. Дейвіс Н. Новини пласкої землі. Київ : Темпора. 2011. 548 с.

3. Дубов Д.В. «Стратегічний наратив»: до проблеми реалізації сутності складової стратегічних комунікацій в Україні. URL: http://www.niss.gov.ua/articles/2377/ (дата звернення: 10.03.2020).

4. Капустян O. Укропи, ватники та ще 30 новітніх слів. URL: https://24tv.ua/ukropi_vatniki_ta_shhe_30_novitnih_sliv_n563072 (дата звернення: 21.03.2020).

5. Колодій А. Про консцієнтальну війну i тверезий глузд у ставленні до влади. URL: https://political-studies.com/?p=1311 (дата звернення: 11.04.2020).

6. Манойло А.В. Государственная информационная политика в особых условиях : моногр. Москва : МИФИ, 2003. 388 с.

7. Панарин И.Н. Технология информационной войны : моногр. Москва : КСП, 2003. $320 \mathrm{c}$.

8. Почепцов Г.Г. Сучасні інформаційні війни. Київ : КиєвоМогилян. акад. 2015. 496 с.

9. Семенчук А.Б. Інноваційні засоби об'єктивації концепту тероризм (на матеріалі англійської мови) : автореф. дис. ... канд. філол. наук : 10.02.04. Херсон, 2010. 20 с.

10. Скандал забезпечений. Як Кремль веде інформаційну війну. URL: $\quad$ https://nv.ua/ukr/opinion/russia-today-sputnik-yak-rosiyavikoristovuye-media-50050708.html (дата звернення: 17.04.2020).

11. Сучасні технології та засоби маніпулювання свідомістю, ведення інформаційних війн і спеціальних інформаційних операцій : 
навч. посібник. / В.М. Петрик, В.В. Остроухов, О.А. Штоквиш та ін. Київ : Росава, 2006. 208 с.

12. Толстой I. Україна і Росія: мовно-політичний фронт. URL: https://www.radiosvoboda.org/a/28351574.html (дата звернення: 21.04.2020).

13. Bernstein C. War Stories. URL: http://writing.upenn.edu/epc/authors/ bernstein/poems/war_stories.html (Last accessed: 17.03.2020).

14. Fuller J.F.C. The Foundations of the Science of War. Saffron Walden : Books Express Publishing, 2012. 340 p.

15. Far-Right Extremists Have Been Using Ukraine's War as a Training Ground. They're Returning Home. URL: https://www.vice.com/ en_us/article/vb95ma/far-right-extremists-have-been-using-ukraines-civil-

war-as-a-training-ground-theyre-returning-home (Last accessed: 27.04.2020).

16. How Russia's worst propaganda myths about Ukraine seep into media language. URL: https://www.stopfake.org/en/how-russia-s-worstpropaganda-myths-about-ukraine-seep-into-media-language/ (Last accessed: 29.04.2020).

17. Malorossiya is a Russian Idea. URL: https://warsawinstitute.org/ malorossiya-is-a-russian-idea/ (Last accessed: 29.04.2020).

18. Only Russia can save Ukraine, Kadyrov tells Poroshenko. URL: https://www.rt.com/russia/427734-kadyrov-russia-save-ukraine/ (Last accessed: 30.04.2020).

19. Ramsay G., Robertshaw S. Weaponising news RT, Sputnik and targeted disinformation. King's College London Centre for the Study of Media, Communication \& Power. 140 p. URL: https://www.kcl.ac.uk/ policy-institute/assets/weaponising-news.pdf (Last accessed: 20.04.2020).

20. Russia Today и Спутнику запретили участвовать в конференции о свободе прессы в Лондоне. URL: https://www.dsnews.ua/world/russiatoday-i-sputniku-zapretili-uchastvovat-v-konferentsii-09072019141000 (Last accessed: 20.04.2020).

21. Spindoctor. URL: https://www.collinsdictionary.com/dictionary/ english/spin-doctor (Last accessed: 26.04.2020).

22. There are real Nazis in power in Kiev. URL: https://www.geopolitica.ru/ en/article/there-are-real-nazis-power-kiev (Last accessed: 22.04.2020).

23. The Geopolitics of Ukraine's 'The'. URL: https://foreignpolicy.com/ 2019/10/05/ukraine-name-insult-war-russia-geography/ (Last accessed: 27.04.2020).

24. There's No Evidence the Ukrainian Army Crucified a Child in Slovyansk. URL: https://www.thedailybeast.com/theres-no-evidence-theukrainian-army-crucified-a-child-in-slovyansk (Last accessed: 28.04.2020). 
25. The Nazi Junta in Kiev must be brought to justice. URL: https://katehon.com/article/nazi-junta-kiev-must-be-brought-justice (Last accessed: 27.04.2020).

26. Ukraine crisis: Donetsk sees deadliest attack on troops. URL: https://www.bbc.com/news/world-europe-27515514 (Last accessed: 28.04.2020).

27. Ukraine's Cryptic, Clever (And Always Insulting) Lexicon Of War. URL: $\quad$ https://www.rferl.org/a/ukraine-lexicon-of-war/26590324.html (Last accessed: 27.04.2020).

28. Vatnost - Why the West can't Understand Russia. URL: http://readrussia.com/2015/06/09/vatnost-\%E2\%80\%93-why-the-west-cantunderstand-russia/ (Last accessed: 29.04.2020).

29. War on terms: who's fighting against Ukraine in Donbas - terrorists, rebels, insurgents? URL: http://euromaidanpress.com/2019/06/04/war-onterms-whos-fighting-against-ukraine-in-donbas-terrorists-rebels-insurgents/ (Last accessed: 30.04.2020).

\section{Information about the author:} Tarasova V. V.,

Candidate of Philological Sciences, Associate Professor at the Department of Foreign Languages Taras Shevchenko National University of Kyiv 60, Volodymyrska str., Kyiv, 01033, Ukraine 